\title{
DISABILITY RIGHTS AND THE EU LABOUR MARKET: AN ANALYSIS OF LEGISLATION AND POLICY
}

\begin{abstract}
Maša Anišić Campbell*
Summary: For Europe's nearly 40 million disabled persons, restricted access to the labour market continues to prevent this group from achieving full inclusion in society. Given Europe's aging society and its emphasis on social welfare protections, excluding disabled persons from entry to the workforce is at first glance an economic problem. This population alone accounts for one of Europe's greatest untapped resources. More important, however, especially for the disabled, the problem is as much an economic one as it is a violation of human rights. This article begins with an examination of the social and medical models of disability, arguing in favour of the former, and provides a brief historical overview of the disability movement. Much of the focus is on the Treaty of Amsterdam, which provided the necessary basis for the Framework Employment Directive, to date the only directive that deals with the prohibition of discrimination of disabled persons in the workforce. This article will then examine the key deficiencies of the Framework Employment Directive regarding disability, notably its failure to provide a definition of disability, and the lack of sanctions and direct effect. This article will then provide some possible solutions to make disability level with other types of discrimination by means of introducing positive duties, mainstreaming, and converging Member States policies.
\end{abstract}

\section{Introduction}

Human rights hold an essential place in the EU legal framework, and over the last sixty years the EU has done much to improve the quality of life for its citizens. For certain groups, however, government, legislative, and administrative bodies have been insufficient in accommodating their needs. Among the most overlooked are those with disabilities. Given the complex design of the EU, Member States have been slow to recognise and implement policies that would help this disadvantaged community. Unlike other minority groups, notably those based on ethnicity or race, the disabled have seen far fewer advances. The key questions that must be addressed by the EU at large is what are the main problems for its 38 million disabled citizens and how can their issues be better addressed by both national and supranational legislative bodies?

Lecturer at University College of International Relations and Diplomacy, Zagreb. 
In light of Europe's current economic malaise, access and entry to the workforce continue to be the disabled community's most pertinent challenge. This problem is becoming more substantial because Europe is faced with a shrinking workforce resulting from demographic changes brought about by an ageing society, and a strong correlation exists between aging and disability. In short, the problem with the disabled is cyclical. Low employment rates contribute to the group's higher dependency on public benefits, which in turn augments public spending percentages on disability and sickness care, and enhances the likelihood that those with disabilities will dwell in poverty, further increasing their dependency on public dole. ${ }^{1}$ In most cases, the working age segment of the disabled community is not even considered among the rest of Europe's unemployed population, negating their access to employment policies. By denying them entry - no matter the reason - the European Union is not only severing off a capable arm of its labour population and overall productivity, but also disallowing its citizens the right to fully participate in society. ${ }^{2}$

Though the problem remains far too overlooked in bureaucratic circles, recent academic examinations reveal a number of troubling externalities resulting from the above, including the fact that disabled women are far more likely to be eschewed from the labour market than disabled men; and those with learning disabilities have far higher unemployment rates than those with physical handicaps.

The figures are troubling. Unemployment rates for the disabled at the EU level are two to three times higher than the average unemployment rate. Disabled persons account for a mere $16 \%$ of the total labour force. The jobless rate for the most seriously disabled is $78 \%$ - a figure that could be easily mitigated with simple improvements to the work space. ${ }^{3}$ Moreover, studies have shown that lapses in unemployment for the disabled tend to be longer than for the rest of the working population, and that when employed, disabled persons have less job security. ${ }^{4}$ Not only do

\footnotetext{
Isilda Shima, Eszter Zolyomi and Asghar Zaidi, 'The Labour Market Situation of People with Disabilities in EU25' (2008) (European Centre for Social Welfare Policy and Research Policy Brief Series February (I)). <http://www.euro.centre.org/data/1201610451_25081. pdf> accessed 12 June 2009.

2 European Disability Forum, 'EDF Response to the European Commission Consultation on Disability Mainstreaming in the European Employment Strategy' (May 2004) DOC EDF 04/03 EN <http://www.edf-feph.or> accessed 22 March 2009.

3 European Trade Union Confederation and European Disability Forum, ‘Joint Declaration' (26-28 October 2007)

'http://www.etuc.org/IMG/pdf_Declaration_commune_de_la_CES_et_du_EFHP_ EN.pdf> accessed 15 May 2009.

4 European Disability Forum, 'Employment' <http://www.edf-feph.org/Page_Generale. asp?DocID=13379> accessed 12 February 2009.
} 
these figures highlight the lack of equal opportunities for a large swath of the European population, they also point to a serious economic concern, namely that otherwise intelligent and capable citizens are being broadly excluded from participation and production activities. Rather, they are draining the public budget at a time when Europe's population is rapidly aging, and its workforce shrinking. In addition to adding pay-in contributors to public benefit and entitlement programmes, the disabled are also an untapped consumer market for products and services that could provide a much needed spark to the European domestic economy.

This article will assess the inclusion of disabled persons in the EU workforce. It will begin with an examination of the two models of disability, medical and social, and conclude that the social model - which the EU has only recently begun to recognise - is far more adept in evaluating and addressing the problems of this population. Next, the article will outline a brief historical overview of the developments in legislation and policy making, specifying their impacts. Special attention is given to Article 13 of the Treaty of Amsterdam, and the Framework Directive for Equal Treatment in Employment and Occupation ${ }^{5}$ as the key milestones in securing better labour policies for the disabled, which have allowed for the creation of innovative solutions and the negation of the more common shortfalls. Next, because the issue of disability rights is not limited to legislation, this article will also analyse some of the corresponding strategies that influence policy making. Finally, the paper will conclude that while a number of corrective measures are in place, further steps need to be taken at the EU level to ensure the better inclusion of the disabled in society.

\section{The models of disability: social vs. medical}

Perhaps the most important element that shapes the formation of policy for the disabled is the most basic: how does one define disability? Perception often defines policy, and for policymakers and academics alike, two vastly different models exist, the medical model and the social model of disability.

The medical model of disability focuses on the disabled person's impairment itself and recognises it as the root cause of the disadvantage experienced by the disabled person. This model recognises the impairment as the fundamental source of a person being classified as disabled and links the physical degree of their handicap to the overall level of their

5 Council Directive (EC) 2000/78 establishing a general framework for equal treatment in employment and occupation [2000] OJ L303/16. 
disadvantage. Those who adhere to this model generally subscribe to the principle that curing (or at least mitigating) their handicap is the key method of remedying a person's displacement in society. ${ }^{6}$

The social model, in contrast, shifts the focus from impairment onto disability, using this term to refer to disabling social, environmental and attitudinal barriers rather than lack of ability. Thus, while impairment is the functional limitation(s) which affects a person's body, disability is the loss or limitation of opportunities resulting from direct and indirect discrimination. ${ }^{7}$

Before 1996, the EU largely targeted the medical model as the key driver of disability policy. In short, the focus was on the individual, rather than society. In other words, the problems related to the impairment were singularly attributed to the person, rather than, for example, an inadequate building code or outdated corporate policy. The medical model is, of course, the more traditional method of understanding disability, which has served to incapacitate and segregate the normal functions of disabled persons for centuries. Since then, however, following the lead of other such minority groups, the disabled community has sought to spur legislative action via a disability rights movement. The European Commission responded with the promulgation of the social model in a policy document entitled 'Communication of the Commission on Equality of Opportunity for People with Disabilities' of 30 July 1996, which stated:

The core value of equality - rendered here as equal opportunities - is now seen as the central benchmark...against which economic and social structures must be assessed. It forms the essence of the rights-based...approach to disability. The equal opportunities ideal is of course broader than that, but nevertheless...subsumes the principle of non-discrimination. ${ }^{8}$

The Head of the European Commission's Unit on the Integration of People with Disabilities went even further to add:

The EU perceives disability as the result of the dynamic interaction between a person and their environment, including social constructions, which lead to discrimination and stigmatisation. It is therefore the environment that should be adapted to each individual person, including people with disabilities, by removing these barriers. ${ }^{9}$

\footnotetext{
6 Liz Crow, 'Including All of Our Lives: Renewing the Social Model of Disability' in Colin Barnes and Geof Mercer (eds), Exploring the Divide (Disability Press, Leeds 1996) 55.

7 Crow (n 6) 55.

8 Commission (EC), 'Communication on equality of opportunity for people with disabilities' (Communication) COM (96) 406 final, 30 July 1996.

9 Wallis Goelen, quoted in ETTAD, 'Disability Legislation in the EU' < http://uk.ettad.eu/ understanding-disability/disability-legislation-in-the-eu> accessed 12 February 2009.
} 
This commitment to equality on behalf of the Commission has helped administer a more socially inclusive approach in terms of recognising that rights must lead to actions, which subsequently lead to opportunities. ${ }^{10}$

As a result of these changes in demarcation and perspective, however, a number of new questions have arisen. ${ }^{11}$ In particular, academics and policymakers have yet to be able to measure accurately the impact of societal wide stereotypes against those with disabilities that have nothing to do with their actual capacities. Consider those infected by the HIV virus - how does one measure the total negative stereotypes these people face at the workplace, despite the fact that the virus has little, if anything, to do with their ability to perform job-related tasks? 'According to this line of thought, full participation of disabled persons in society was not prevented by the physical or psychological limitations of disabled people themselves, but by the social restrictions imposed upon them'. ${ }^{12}$

Despite the complexities resulting from the new model, the EU's embracement of the social model has been a boon to proponents of disability rights and equal opportunities. In addition, those bearing the burden of physical handicaps are perhaps alleviated of the consummate stress of believing that they are the problem, rather than the building that lacks satisfactory ramps and entryways, since, according to the social model, a person in a wheelchair is not limited by the fact she cannot use her legs, but by the fact that the infrastructure regarding wheelchair ramps in her surroundings is insufficient. ${ }^{13}$

Though much of the thrust behind the European Union's enactment of the social model is the result of changes in administrative attitudes toward civil rights, these policies are also partly borne out of basic economic concerns. The cost of preventing those from accessing the workforce, ensuring their welfare and healthcare costs, while factoring in the loss of taxes and contributions paid as a result of working, proves to be an unsustainable model for economic growth. Thus, the EU has begun to expedite the reforms brought on by attitudinal changes by incorporating the economic factors, the social model, and the civil rights approach, ie

\footnotetext{
10 European Policy on Disabled People and the Position of Disabled People, 'European Policy on Disability and the Position of Disabled People' (QUATRAIN2 Project No: LLP-LdV-TOI2007-UK-065)

‘http:/ / uk.qatrain2.eu/european-policy-on-disabled-people-and-the-position-of-disabled-people> accessed 4 April 2009.

11 Lisa Vanhala, 'Fighting Discrimination through Litigation in the UK: The Social Model of Disability and the EU Anti-Discrimination Directive' (2006) 21(5) Disability \& Society, 562.

12 Carol Daugherty Rasnic, 'ADA: A Model for Europe with "Sharper Teeth"' (2004) 11 ILSA Journal of International and Comparative Law, 114.

${ }^{13}$ Mark Bell, 'The Implementation of European Anti-Discrimination Directives: Converging towards a Common Model?' (2008) 79 (1) Political Quarterly 40.
} 
allowing for increased legal remedies to confront behaviour deemed discriminatory.

In fact, since the European Commission's revision in policy, disability rights have been given a clearer legislative basis in the Member States' policies as well. The Irish Disability Act of 2005, perhaps the most substantive piece of legislation in the field of disability law in Europe, is divided into seven different parts and encompasses many of the ideals promoted by the social model, including the protection and enablement of quality health and education opportunities for those with disabilities, an increased allotment of funds to these programmes, guarantees to ease access ways at all public buildings, and most relevant to this study, the promotion of employment for disabled persons in the public sector.

In summary, the EU has opted for the social model of disability, and thus opened the door to other actions to include the disabled. Where the medical model offers only a recognition and rehabilitation of the disability itself, the social model offers different mechanisms that deal with eliminating the barriers of which the most important are positive duties, which will be discussed more substantively later in this article.

\section{A historical overview of disability rights development in the EU}

Under the realm of human rights issues, disability rights are among the youngest, and therefore least recognised. An overview of EU acts related to disability suggests that they have consistently fallen behind the more recognised human rights issues, specifically those based on gender, race or nationality. An analysis of the Framework Employment Directive, however, will show that disability issues have begun to be acknowledged and the steps to ensure the equality of people with disabilities have begun to be taken.

Prior to the formation of the European Union, when Member States worked under the framework of the European Economic Community (EEC), disability rights were largely ignored. When disability rights were delved into, notably in the 1960 s, the basis was not to promote labour equality, but rather to harmonise existing policy throughout the economic bloc and to expand the capacities and skills of those with disabilities in the workforce; a concept much in line with the prevailing medical model to fix the disabled person, rather than his or her environment. This is hardly surprising when one takes into account that the purpose of the EEC was to create a geographical entity comprised of signatory Member States for economic consistency. As such, the primary instruments in place to decrease the existing employment cleavages during the EEC's formative years were training programmes and vocational rehabilitation. In 1974, the first Community Action Programme that highlighted the 
high disparities of unemployment between the disabled and non-disabled, as well as recognised the disabled as a particular group experiencing workplace discrimination, was enacted. Disability rights policies in the 1980s continued to be handled with the same measured responses, albeit with a slightly softer approach that hinted at the movement towards the social model. These include the 1981 Resolution on the Social Integration of Handicapped People, which invited Member States to ensure that handicapped people did not shoulder an unfair burden of the effects of economic adjustment ${ }^{114}$ and the Recommendation on the Employment of Disabled People in the Community from 1986, which urged employers to remove negative discrimination in the workplace and increase fairer job security measures for those with disabilities. Though it provided no safeguards or actual legislation, the EEC also recommended employers to adopt equal employment measures, or rather positive action, in the form of hiring quotas and workplace codes of better business practice.

Much more significant to today's model of policymaking was the EEC's creation of three separate community action plans for the disabled: the first went unnamed; the second and third were known as HELIOS I and HELIOS II, respectively (Handicapped People in the European Community Living Independently in an Open Society). These programmes, spanning the 1980s and the first half of the 1990s, sought to improve lines of communication between the disabled community, the private sector, and legislative bodies by encouraging the formal exchange of ideas and techniques to improve business practices in the EEC (and subsequently EU) Member States. The key positive externality of the HELIOS programmes was the mobilisation of the disabled community as a group (or set of groups). In addition, the programmes mobilised awareness and encouraged the full participation of the disabled community in policy making. ${ }^{15}$ Among the most significant of these groups, the European Disability Forum (EDF), a loose affiliation of disabled groups hailing from different Member States, was almost entirely funded by the HELIOS II programme (1993-1996) and has championed the civil rights model of disability activism. The EDF has staked its primacy in the community and is responsible for the majority of lobbying efforts at the EU level. '...[W] ith the arrival of EDF at the EU, disability began to be seen as a matter fit for non-discrimination policies, a mechanism that the EU had before only considered in the context of race and gender'. ${ }^{16}$

\footnotetext{
14 Mark Priestley, 'Why We Need to Work Together in the European Year of Disabled People' (2002) 17 (7) Disability \& Society 846.

15 Andre Gubbels, 'The Evolution of EU Disability Policy: From Charity towards Rights'

‘http://www.nuigalway.ie/law/Disability_summer_school/Docs/2006/Andre\%20 Gubbels\%201\%20-\%20Teaching\%20summary.pdf> accessed 23 April 2009.

16 Thomas Burke, 'The European Union and the Diffusion of Disability Rights' in MA Levin \& M Shapiro (eds), Transatlantic Policy-Making in an Age of Austerity: Diversity and Drift, (Georgetown University Press, Washington, DC 2004) 53.
} 
Thanks in part to the United Nation's (UN) policy action plan, the Standard Rules on the Equalization of Opportunities for Persons with Disabilities (1993), the EU began the slow process of enacting policy based on the social model rather than the medical one. As previously noted, 1996 was the landmark year of the disabled in Europe. In addition to hosting a European Day of the Disabled, the European Commission (and later the European Council) adopted the landmark, 'Equality of Opportunity for People with Disabilities: A New European Community Strategy'. The communique featured a historic shift in thinking: the major challenge for the disabled is not the disability itself, but rather the overt and latent discrimination of society. Further, the resolution directed Member States to approach disability through a rights-based model built on two key standards: 'the principle of equality of opportunity in the development of comprehensive policies in the field of disability' and 'the principle of avoiding or eliminating any form of negative discrimination on the sole grounds of disability'. ${ }^{17}$ These recommendations soon gained punitive grounds in the EU-wide Treaty of Amsterdam (1997). Article 13 of the Treaty, which will be explained in more detail later in this article, enabled the EU to take legal action against discrimination inflicted upon the disabled (as well as other minority groups), which under prior treaties had been limited to discrimination based on gender and nationality.

The key contribution of the Treaty of Amsterdam's Article 13 was that it provided the legal basis for the EU's most formidable legislation in the realm of disability: the Framework Employment Directive. The Framework Employment Directive - its significance will be further expanded upon below - barred any form of discrimination in the workplace (or vocational training facility) on the grounds of religion or belief, age, sexual orientation, and disability, and led directly to a more comprehensive five-year Anti-Discrimination Action Programme to compel legislative and administrative bodies to compile research, raise awareness, and, where available, support and strengthen the mechanisms of non-governmental organisations (NGOs) to do the same. Soon thereafter, the European Congress of Disabled People congregated in March 2002 to put together an action agenda for the upcoming European Year of Disabled People (2003). Though the conference refrained from setting any innovative policy objectives (its most noteworthy contribution was the adoption of the Madrid Declaration - a three-tiered effort by the EDF, the Spanish Presidency of the European Council, and the European Commission - that recognises disability as a basis for discrimination), the meeting was largely diverse - attended by more than 600 participants hailing from 34 different countries.

17 Resolution of the Council and of the Representatives of the Governments of the Member States meeting within the Council of 20 December 1996 on equality of opportunity for people with disabilities (97/C 12/01). 
Though the creation of the EDF and the adoption of Treaty of Amsterdam and the Framework Employment Directive have been crucial in creating the foundation for improved working and social conditions for people with disabilities, many questions persist on how to implement practical steps toward eradicating the general population's long-held stereotypes on both the physical and mental capacities of the disabled. More than encroaching on the sensitivities of the disabled, these stereotypes often reinforce negative environmental discriminations - inaccessible entryways, obstructive pathways - and costly economic prescriptions that actually endorse more discrimination and serve to isolate the disabled.

\section{Article 13 of the Amsterdam Treaty: a foundation for a new approach}

For the European disability movement, Article 13 was by far the highlight of the Amsterdam Treaty. Though considered softer and less wide reaching than the historic Treaty of Maastricht (1992), its predecessor, the Treaty of Amsterdam galvanised the anti-discrimination movement, expanded support across various populations, and set in motion a path for legislation. In fact, its codification in the treaty was the result of a lengthy campaign by an unlikely coalition of various NGOs. ${ }^{18}$ Though brief in appearance and broad in scope, Article 13 allowed the EU to 'take appropriate action to combat discrimination based on sex, racial or ethnic origin, religion or belief, disability, age or sexual orientation'. ${ }^{19}$ It states as follows:

Without prejudice to the other provisions of this Treaty and within the limits of the powers conferred by it upon the Community, the Council, acting unanimously on a proposal from the Commission and after consulting the European Parliament, may take appropriate action to combat discrimination based on sex, racial or ethnic origin, religion or belief, disability, age or sexual orientation. ${ }^{20}$

\footnotetext{
18 There were two other important measures, but in both the lobbyists were disappointed. First, an amendment had been sought to Article 100A (now 95) on single market harmonization which would ensure that harmonized standards took account of the needs of disabled people. In the end, a declaration was appended to Article 100A instead. Second, Article 118 (now 137) specified the fields in which the Community "shall support and complement the activities of Member States". These included "the integration of persons excluded from the labor market" and "opportunities and treatment at work", but there was no specific mention of disability in the final version of the Treaty, although there had been in the penultimate text.' Deborah Mabbett, 'The Development of Rights-Based Social Policy in the European Union: the Example of Disability Rights' (2005) 43 (1) Journal of Common Market Studies 97, 101.

19 Treaty establishing the European Community (Nice consolidated version) - Part One: Principles - Article 13, Official Journal C 325, 24/12/2002 P. 0043 - 0043, Official Journal C 340, 10/11/1997 P. 0185 - Consolidated version <http://eurlex.europa.eu/LexUriServ/ LexUriServ.do?uri=CELEX:12002E013:EN:HTML>

20 Treaty establishing the European Community (n 19).
} 
As noted above, prior to Amsterdam, the EU only addressed discrimination against individuals on the grounds of nationality (Article 12 EC, ex Article $6 \mathrm{EC}$ ), and sex, in the limited area of equal pay for equal work for men and women (Article 141 EC, ex Article 119 EC)..$^{21}$ Article 13 is far broader in its scope. Furthermore, unlike Articles 12 and 141, Article 13's inclusion in the Treaty was not primarily prompted by the desire to combat discrimination for economic reasons or to complement the single market. Instead, it is part of a trend which arguably is presently reflected more in rhetoric than in reality: to bring Europe 'closer to the citizens', ${ }^{22}$ a vague notion that falls in line with the purposefully ambiguous text of the article.

Under the provisions of the article, the EU is granted the ability to take 'appropriate action'. To the dismay of many, there is no further mention of what 'appropriate action' may entail, though legal experts suggest that the ambiguity allows for the use of all legal instruments referred to in Article 254 EC (ex Article 191 EC), and most probably the use of action programmes. Though as Waddington suggests, "the requirement that the action be "appropriate", meaning in the first instance presumably "appropriate" in the eyes of the Commission, European Parliament, and above all else the Council, imposes a restriction on the kinds of instruments adopted'. ${ }^{23}$

Despite Article 13's far reaching impact, there are several areas worth noting where the language fell short - specifically in the eyes of anti-discrimination proponents. First, the article did not allow for direct effect on EU Member States' national legal systems. The experience with Articles 12 and 141 EC shows the far-reaching non-discriminatory impact a provision with direct effect can have; the impact of Article 13 is, by comparison, proportionately far less.

A second criticism of Article 13 is that the European Parliament's role in arbitrating or consulting with regard to anti-discrimination provisions is rather limited. In spite of these criticisms, few can discount Article 13's importance in the battle against discrimination. Beyond its symbolic act of adopting more socially conscious language and ideals, the article gave birth to an EU wide legal instrument to combat both direct and indirect forms of discrimination, and enhanced the 'scope for "positive action" in areas where there was no prior Treaty competence'. ${ }^{24}$ Most

\footnotetext{
${ }^{21}$ Mark Bell, 'Article 13 EC: the European Commission's Anti-Discrimination Proposals' (2000) 29 (1) ILJ 79, 84

22 Lisa Waddington, 'Testing the Limits of the EC Treaty Article on Non-Discrimination' (1999) 28 (2) ILJ 133, 137.

23 Waddington (n 22) 137.

24 Andrew Geddes and Virginie Guiraudon, 'Britain, France, and EU Anti-Discrimination Policy: The Emergence of an EU Policy Paradigm' (2004) 27 (2) West European Politics 334, 340.
} 
importantly, its promulgation led directly to the Framework Employment Directive, the single most important legislative act of the EU dealing with the disabled people.

\section{The Framework Employment Directive}

Since the general principles of Article 13 are not themselves legally binding, to give effect to Article 13, the Council of Ministers approved two directives proposing minimum standards of legal protection against discrimination throughout the EU. The first, the Racial Equality Directive, codified the principles of equal treatment of persons regardless of their ethnic or racial background. The second, the Equal Treatment Framework Directive, also known as the Framework Employment Directive, 'protects individuals against discrimination based on religion, belief, disability, age or sexual orientation'. ${ }^{25}$ Of course, the Framework Employment Directive is far more expansive than just a reiteration of Article 13's principles. The Directive applies to all forms of discrimination - both direct and indirect and all areas of employment, including the public and private sectors, vocational training centres, salary compensation, working conditions, and membership in unions or other workers organisations. ${ }^{26}$ The Directive applies to all natural and legal persons in the European Union, regardless of whether they are nationals of Member States, and to both public and private employers (whatever the size of the company or the number of employees).

The key facet of the Directive is that it enforces a minimum standard that all Member States must adhere to; however, the specifics are left entirely to the national legislative bodies in terms of how strictly these policies are to be enforced. In other words, Member States are free to utilise their own methods of implementation and set their own standards and enforcement policies so long as they commit to the minimum standard outlined in the Directive. Furthermore, the Directive puts the weight of its focus on the result. The means by which this result is attained by each Member State's domestic laws and enforcement capacities are left entirely to their own discretion. ${ }^{27}$ Each Member State's progress, specifically during the implementation phase, is monitored by an EU appointed group of experts. This group is made up of one expert in the field of disability law from each Member State.

Despite the uniquely European characteristics of the Directive noted above, the Employment Framework Directive took the majority of its

\footnotetext{
25 Lisa Vanhala, 'Fighting Discrimination through Litigation in the UK: The Social Model of Disability and the EU Anti-Discrimination Directive' (2006) 21 (5) Disability \& Society 551, 561.

26 Council Directive (EC) 2000/78 (n 5).

27 Rasnic (n 12) 124.
} 
language and intents from the landmark Americans with Disabilities Act (ADA) (1990). Both the ADA and the Framework Directive put in place systems to protect employers. The ADA scripted this in its 'undue hardship' defence, while the Framework Directive provides assurances that it will recognise costs and organisational restraints, as well as provide public funding where available to aid employers in making the necessary accommodations at the workplace to allow disabled persons easier access. Moreover, the ADA's guarantee of 'reasonable accommodation' for disabled persons is quite overtly referenced in the Framework Directive's 'provision of measures to accommodate needs of disabled people at the workplace' and the '... obligation to provide reasonable accommodation for people with disabilities'.

While each Member State was to have implemented the Directive by 2 December 2003, few of them actually complied. Despite the potential for punishment, which includes a Member State being brought before the court in Luxembourg, the European Commission has 'proved to be a patient parent'. ${ }^{28}$ To date, no sanctions or punishments have been given. In addition, because of the Directive's complexity and overwhelming impositions on the status quo - especially where they regarded discrimination against age and disability - the Directive, in Article 28, paragraph 2, allowed Member States an extension period of up to three years for the implementation of these provisions into national law. Indeed, by the end of 2006, all Member States had successfully adopted the minimum standards stipulated by the Directive, thereby completing the largest legislative overhaul in the history of the European Union in terms of disability law. Though far from perfect, given the enormity of differences that exist between what the Directive stipulated and what has actually been implemented into national law, the European Union has both positively reformed twenty-seven different sets of national law - hardly an easy task - and achieved the main goal intended by Article 13: to bring the EU 'closer to the citizen'.

At the national level, the Framework Employment Directive was perhaps most overwhelming for the 2004 and 2007 EU entrant states; however, "perhaps more unexpected is the considerable impact of the Directives even in those states where anti-discrimination law already had a well established tradition' ${ }^{29}$ In light of this, many experts suggest that the true success of the Directive remains to be seen. It is contingent on a number of factors, including the ability of individuals to work within the new legislative systems, as well as whether or not NGOs and civil society groups have any further effect on raising the minimum standar-

28 Bell (n 13) 42.

29 Bell (n 13) 42. 
ds within already established national legislations. Further, how capable will NGOs and civil society groups be in terms of penetrating beyond national borders to create a second round of Europeanization where this concerns anti-discrimination policies? The Directive introduces positive approaches to labour discrimination law that are new and inspiring. Employment is defined widely; it includes all types of vocational training, self-employment and participation in employee/employer organisations (Article 3). ${ }^{30}$ There is also a provision for positive action measures (Article 6), as well as allowance for a shift in the burden of proof in actions to enforce the equal treatment principle (Article 9).

But, even though the Framework Directive remains the single most important European instrument driving disability law and policy forward in European nation states at the moment, ${ }^{31}$ it contains deficiencies, which concern the definition of disability, the concept of 'reasonable accommodation,' the inability to enforce or impose sanctions, the absence of 'direct effect', and 'the absence of any systematic mechanism to monitor Member States' implementation', ${ }^{32}$ which will be the focus of the following sections.

When discussing the direct effect of Article 13, one should not omit to note the new tendencies created by the Baumbast ${ }^{33}$ judgment, in which the ECJ declared Article 18 of the EC Treaty to be directly effective by making clear that the right of residence under the article was conferred directly on every citizen of the Union by virtue of a clear and precise provision of the EC Treaty, and thus opened the gate for the direct effect of other fundamental rights provisions.

\subsection{The elusive definition of disability}

According to the Framework Employment Directive, the definition of disability is a matter of national competence. While this may be considered positive in terms of upholding the sovereignty of Member States, it serves to undo the objectives of the Directive when disability is too narrowly defined. And just as some countries have confined their definitions, others have instituted a threshold in the severity of a disability (based on percentages and statistics) that restricts the number of people covered by disability legislation, and draws the movement back towards the medical model of disability. Had the definition been clearly stated in the Directive, all Member States would have been obligated to follow the same definition, and the personal scope of the Directive would have been

\footnotetext{
30 Bell (n 21) 84.

${ }^{31 \mathrm{~B}} \mathrm{ell}$ (n 21) 87.

32 Bell (n 21) 88.

33 Case C-413/99 Baumbast and $R v$ Secretary of State for the Home Department [2002] ECR I-7091.
} 
the same throughout the EU, which would prevent the divergence of case law among the states and streamline the task of the European Court of Justice (ECJ).

The Directive's silence on the definition of disability creates a potential for decisions to be affected by national social policies. This is particularly important where it applies to the allocation of public funds. For example, a disabled person may be reasonably accommodated through the aid of a public contribution to a private company that alleviates the physical barriers in the workplace. Yet if a person's disability does not adequately correspond to the administrative definition, public funding will likely be unavailable.

Another problem can be seen in the states that institute a quota system. In cases where the definition of disability corresponds to the definition used by the quota system authorities, then the quota could be used to evaluate how well an employer complies with the anti- discriminatory practice outlined in the Directive. Disabled persons, in these instances, may have to take complaints to the administrative body in charge of the quota.

These examples suggest that it is possible that the development of European disability discrimination law will be limited, essentially because of the close relationship between the operation of the law and domestic social policies. ${ }^{34}$

It still remains unclear how the ECJ will influence the Member States' policymaking in the field of disability. As one can see from the gender equality case law, at times the ECJ has come down hard on Member States social policies regarding equal treatment (ie, the case of Abrahamsson). ${ }^{35}$ Yet in other instances, Member States have proven to be proficient in defending their respective national social programmes. ${ }^{36}$ As Fitzpatrick notes, '[T] he Court is less autonomous in this field than might otherwise be anticipated, even in relation to a fundamental social right such as equality irrespective of sex'. ${ }^{37}$

A further effect of the Directive's silence in defining disability is that it renders unclear who belongs to the group of people that are entitled to claim protection from discrimination. In these cases, national legislatures most often seek preliminary rulings from the ECJ, overburdening the Court with cases concerning solely the personal scope of the Directive.

\footnotetext{
34 Mabbett (n 18) 101.

35 Case C-407/98 Abrahamson v. Fogelquist 2000 ECR I-5539.

36 Daniela Caruso, 'Limits of the Classic Method: Positive Action in the European Union after the New Equality Directives' (2002) Jean Monnet Working Paper 10/02 11.

37 Barry Fitzpatrick, "Converse Pyramids and the EU Social Constitution" in J. Shaw (ed), Social Law and Policy in an Evolving European Union (Hart Publishing, Oxford, Portland 2000) 318.
} 
By far the most worrying problem connected to the lack of a definition is that it has the potential to revert EU-wide policy back to the outdated medical model. In spite of the Directive's overwhelming emphasis on the social model, and the European Commission's, European Council's, and European Parliament's approbation of the said model, the ECJ's judgment in one particular case, Chacón Navas, ${ }^{38}$ revealed its tendency to favour the medical model. The court, asked to judge whether someone dismissed by an employer due to sickness is protected by the Directive, delivered a two-pronged decision that negates much of the Directive's social competencies. First, the ECJ argued that disability must have a uniform definition throughout the Member States so that legislation is consistently applied across the union. The Court began by deciding that "disability" must have, within Community law, a uniform interpretation in order to ensure consistency across the Member States' ${ }^{39}$ In doing so, however, the ECJ merely required Member States to impose a minimum standard of antidiscrimination disability law, which, for the majority of Member States, required no further action as they had already implemented the minimum standards. As well, in terms of the Europeanization of laws, the Court favoured a lowest common denominator approach that permitted states to retain the outdated medical model of disability. ${ }^{40}$

Second, and perhaps more harmful to the EU's adaptation toward the social model, the Court emphasised its promotion of the medical model by drawing a fixed line between short-term 'sickness' and long-term 'disability': ${ }^{41}$

[T] he concept of 'disability' must be understood as referring to a limitation which results in particular from physical, mental or psychological impairments and which hinders the participation of the person concerned in professional life. . . . In order for the limitation to fall within the concept of 'disability', it must therefore be probable that it will last for a long time. ${ }^{42}$

The EDF responded that 'the Court's judgment showed a lack of understanding of the social model and relied on an out-dated medical approach in developing a definition of disability for the purposes of the Directive'. ${ }^{43}$

38 Case C-13/05 Sonia Chacón Navas v Eurest Colectividades [2006] ECR I-6467, para 42.

39 Ibid.

40 Bell (n 13) 43.

41 'Proposal by the European Disability Forum for a Comprehensive Directive Fighting Discrimination of Persons with Disabilities' (2008) (DCC EDF, January 2008)

‘http://cms.horus.be/files/99909/MediaArchive/Disability\%20Specific\%20Directive. pdf $>$ accessed 17 June 2009.

42 Case C-13/05 Sonia Chacón Navas v Eurest Colectividades [2006] ECR I-6467, para 44.

43 'Proposal by the European Disability Forum' (n 41). 
At the national level, interpretations and implementations of the Directive vary. In fact, only a small number of Member States actually define disability under the requisites of the social model, whereas many simply do not define it at all. In providing protection against discrimination, Dutch law distinguishes between temporary and chronic disease, giving protection only to the latter; its norms grant protection only for 'an actual or assumed disability or chronic disease'. ${ }^{44}$ Far too many Member States not only lack a quality definition of what constitutes disability, but also rely on the medical model which stems from legislation that predates the Framework Employment Directive and incorporate the disabled in with other social entitlement programmes that fail to recognise or accommodate the groups' need for improved physical spaces. The most substantive disability laws in Germany, for example, utilise the above-mentioned percentage system, allowing for the protection of disability rights only when the disability is 'severe': 'reasonable accommodation' is only allotted for those whose disability reduces their labour participation by fifty percent, or 'where the disability is more than 30 per cent if the person cannot find employment as a result'. ${ }^{45}$ In France, one must be officially recognised as a disabled person, and therefore qualify for a disability pension, in order for 'reasonable accommodation' to apply, thereby limiting the number of people who could potentially be covered.

The legislator is accountable for the task of defining the personal scope of the law. Therefore, it is improper for the Commission to delegate this responsibility to the ECJ. Given this, the Directive should have provided better counselling as to what exactly constitutes a disability. Moreover, the Directive should have made clear that discrimination related to disability may also affect those who are not disabled. In other words, it should embrace all those who may suffer from such discrimination. Of course, these persons 'would still need to establish a prima facie case of disability discrimination before they could rely on the relevant legislation, and this broad personal scope would not lead to spurious claims that consume large amounts of court time'. ${ }^{46}$

\subsection{The paradox of reasonable accommodation}

One result of the introduction of disability as an anti-discriminatory ground is the enshrinement of the concept of 'reasonable accommodation', specified in Article 5 of the Directive. 'Reasonable accommodation' pertains only to the ground of disability, given the unique needs of the disabled. It obligates EU Member States to force employers and/or private companies to make certain alterations to the workspace in order to ease physical

\footnotetext{
44 Bell (n 13) 40.

45 Bell (n 13) 40.

46 'Proposal by the European Disability Forum' (n 41).
} 
barriers for disabled persons. 'Reasonable accommodation' is a necessary compliment to the Directive's original objective; however, several problems exist as a result of its inclusion. In order to fully argue these relevant points, a more detailed description of the clause must first be provided.

The full text of the 'Reasonable Accommodation' provision provided by the Framework Employment Directive is as follows:

In order to guarantee compliance with the principle of equal treatment in relation to persons with disabilities, reasonable accommodation shall be provided. This means that employers shall take appropriate measures, where needed in a particular case, to enable a person with a disability to have access to, participate in, or advance in employment, or to undergo training, unless such measures would impose a disproportionate burden on the employer. This burden shall not be disproportionate when it is sufficiently remedied by measures existing within the framework of the disability policy of the Member State concerned. ${ }^{47}$

The most common of these social model measures to accommodate the disabled in the workplace include improving environmental conditions in the workplace, such as wider corridors and entry ramps, easing the abilities of the visually or hearing impaired to utilise system and informational technologies, and adjusting working hours and schedules where necessary. Should a private employer fail to make these and other 'reasonable' adjustments, they may, under the terms of the Directive, be deemed discriminatory. The goal, as mentioned in the article, is to ensure full access, participation, and potential for advancement for the disabled - just as any other employee would be granted - yet, because of the highly disparate conditions for each disabled person, each situation must be handled on a highly individualised basis. Many Member States, it should be noted, have used the same terminology of Article 5 when writing their own national laws and policies.

An issue that needs to be resolved is the definition of 'reasonable accommodation'. The clause itself was far too unique and innovative to be described so vaguely. Prior to the Directive, no other discriminated group warranted such an individualised right that would guarantee their ability to participate and advance in the labour market. Unfortunately, 'the Directive only provided limited guidance on what was meant by the obligation and Member States were, for the most part, left in the dark when it came to transposing and interpreting the provision'. ${ }^{48}$

47 Council Directive (EC) 2000/78 (n 5) art 5.

48 Lisa Waddington, 'When it is Reasonable for Europeans to be Confused: Understanding When a Disability Accommodation is "Reasonable" from a Comparative Perspective' (2008) 29 (3) Comparative Labour Law \& Policy Journal 317, 321. 
Some Member States, however, have altered the Directive's original phrasing of the term, which has subsequently narrowed the scope of what constitutes 'reasonable accommodation'. Finnish law substitutes the term 'accommodation' with 'steps'. Likewise, Great Britain favours the term 'adjustments'. While these may be interpreted as more benign modifications, Irish and French law go even further in redefining the term 'reasonable accommodation', putting the emphasis on the employer, rather than the disabled. Both impart: "a "reasonable accommodation" is one that does not result in "excessive" difficulties being experienced by the employer and considering jurisdictions that have adopted this approach'.49 Not only does the interpretation encroach on the goal of 'reasonable accommodation' - to enable the disabled to participate and advance in a given workplace - but also focuses on the burdens of the employer, rather than the interest of the disabled individual. Germany goes even further in mitigating the Directive's original definition and intention. The German Equal Treatment Act of 2006, enacted to transpose the Directive, makes no reference to the term 'reasonable accommodation'. Instead, the German Social Law Code allows for a disabled person to request additional work-related benefits or workplace adaptations; however, these are not covered in the framework of discrimination, but rather positive duty. Moreover, as was noted above, this applies to only the most severely disabled in society - which again diminishes the Directive's scope to ensure a higher state of equality for all those with disabilities.

Accentuating the problems mentioned above, the European Court of Justice has yet to cast judgment on the issue (of course, it has been handled at the national level with varying degrees of interpretation). This highlights yet another issue with the language of the Directive: it cannot be interpreted equally across the EU and it allows far too much discretion for each Member State's social policies - the ECJ must now render its own definition of 'reasonable accommodation'. Similar to the problems of the definition of disability, the ECJ could again base its interpretation on the medical model.

It should not be left unsaid that Article 5 provides only the minimum of obligation for the states, and that they are welcome to enact stronger obligations on the employers to provide accommodation for their disabled employees. The final sentence in the 'reasonable accommodation' clause states: 'This burden shall not be disproportionate when it is sufficiently remedied by measures existing within the framework of the disability policy of the Member State concerned'. ${ }^{50}$

Essentially, this means that an employer cannot claim a burden to

\footnotetext{
49 Waddington (n 48) 321.

50 Council Directive (EC) 2000/78 (n 5) art 5.
} 
be disproportionate if provided an offer of financial assistance from the state to improve or dismantle the barriers in the workplace. Yet again, Article 5 of the Employment Equality Directive allows for Member States to interpret what these measures are. States have implemented a number of different burden sharing policies, the most common being monetary contributions for workplace changes, various subsidy programmes that aim to increase the employment rates of the disabled, and the implementation of quotas. Because Member States are able to decide their own policies, some might suggest that the ECJ will choose not to impose its own interpretation of 'reasonable accommodation'.

\subsection{The lack of sanctions}

Though few can argue with the Directive's recognition of antidiscrimination protections, one of the main barriers to its effectiveness is that it lacks the ability to force Member States to adequately punish those in breach of the Directive. In this regard, many of the intended actions of the Directive are not taken seriously by the disabled, by those who employ the disabled, or by the courts which render judgments involving discrimination at the workplace. Imposing guaranteed safeguards for the disabled would not only present a form of justice to the disabled person, but would also serve as a deterrent and educational tool to employers. The language of the Directive, referenced below, is, however, far too vague and allows for far too much interpretation at the national level. Article 17 of the Framework states:

Member States shall lay down the rules on sanctions applicable to infringements of the national provisions adopted pursuant to this Directive and shall take all measures necessary to ensure that they are applied. The sanctions, which may comprise the payment of compensation to the victim, must be effective, proportionate and dissuasive. Member States shall notify those provisions to the Commission by 2 December 2003 at the latest and shall notify it without delay of any subsequent amendment affecting them. ${ }^{51}$

The only stated sanction is that an employer may have to pay compensation to the victim; however, monetary fines themselves are perhaps not enough to dissuade a prosperous employer from continuing to pursue policies that are contrary to the Directive. For example, nothing in the language exists about the 'court of public opinion', where an employer would be publicly shamed from his or her discriminatory actions, a punishment that may be far harsher in terms of an employer's future business dealings.

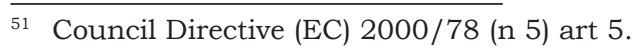


Even though Member States have imposed various interpretations and instruments regarding the above 'sanctions', for the vast majority of states, 'the sanctions foreseen in the legislation are considered by the disability movement as purely ineffectual'. ${ }^{52}$ Danish law concedes the possibility to impose sanctions, but makes no specific mention of what these may entail. In Austria, employers guilty of not meeting the guidelines set in the Directive may be either forced to provide the lost opportunity (be it employment, advancement, or vocational training), or forced to pay compensation to the disabled person. In either case, however, few dissuasive or educational elements exist outside a limited monetary loss.

One could look to judicial protection for disability rights, as the vehicle for the enforcement of sanctions. As noted above, the ECJ has ruled on several cases; but its duty in those particular instances was more to establish a definition for the term disability than to focus on the sanctions for the Member States. Article 9 of the Framework Employment Directive explains that Member States must create 'judicial and/or administrative procedures, including where they deem it appropriate conciliation procedures ${ }^{53}$ for persons bringing forward cases involving workplace discrimination. As a result of allowing the Member States to determine the exact judiciary function, there exist wholly different interpretations of what constitutes 'appropriate measures'.

Some states, acting on a precedent established in the Race Directive (which preceded the Directive) have created independent bodies, often known as Equal Treatment Commissions, whose primary function is to monitor the implementation and compliance where it regards antidiscrimination policies. Some states have granted the judiciary branch the power to oversee and judge individual cases; others only allow judges to act as a consultant. Some states require that cases first be heard by a trade union; others direct individuals to a national arbitrator or ombudsman. Some states avert the judiciary entirely. Cases are instead held before a commission made up of their peers rather than legal experts.

There are several problems with having such a disparate system of justice where it regards the disabled. First, national social policies may impact this area of the law. For example, Germans may deem a disabled person's handicap to be not severe enough to warrant a hearing. Second, many national judicial systems are unaware of both their and the ECJ's powers. 'In the Netherlands and Ireland, the legal bodies that deal with equality cases in the first instance do not see themselves as authorised to refer cases to the ECJ'. ${ }^{4}$ Third, the disparate judicial protections exi-

\footnotetext{
52 Waddington (n 22) 137.

53 Council Directive (EC) 2000/78 (n 5) art 5.

54 Karen J Alter, 'The European Union's Legal System and Domestic Policy: Spillover or Backlash?' (2000) 54 (3) International Organization 489, 496.
} 
sting at the national level affect the formation and abilities of NGOs and other equal rights groups. As a result, little evidence exists to suggest that these NGOs at the national level are even seeking to overhaul the current systems.

There are some questions about the viability of enforcing disability policy in the courts. For much of its history, human rights cases in the European Union have been 'excessively judicially-focused' and that 'too much faith is placed by the Community in the power of legal prohibitions and judicial enforcement'. ${ }^{5}$ Yet the majority of disability rights groups and campaigners tend to favour judicial protections over other enforcements. For many "access to the court system is the "gold standard" for rights'. ${ }^{56}$ Of course, judicial rights will most likely continue to be hampered by the discord existing in the Member States' policy approach to disability rights.

Increasingly, the EU has also begun to shift away from individual litigation as the sole (or primary) instrument to protect the disabled and other minority or exploited groups. This new direction hopes to curtail discrimination before it requires legislative action.

\subsection{The exclusion of direct effect}

The problems noted above all relate to the specific language (or lack thereof) of the Framework Employment Directive. The fourth major criticism of the Directive, however, pertains to its impact. Since the Directive does not have direct effect, it needs to be implemented into the national laws of Member States in order to produce its intended effect. This renders the Directive far less effective, since problems occur in the process of transposition in Member States, for example in the definition and adaptation of language and terminology.

Though all states have passed a minimum standard of the Framework Employment Directive, there exists - as noted above - far too many discrepancies in the particulars of the legislation which negate its usefulness. Even worse, some states have hastily adopted legislation in line with the directive without also dismissing pre-existing legislation that contradicts or conflicts with the Directive.

As noted above, the variables surrounding a person's disability and potential for discrimination are far different from those based on age, gender, sexual orientation, or any of the other grounds covered in the Directive. Legal protections, therefore, must have a more substan-

55 Philip Alston and Jane Weiler, “An Ever Closer Union” in Need of a Human Rights Policy: The European Union and Human Rights' (1999) 9 European Journal of International Law 658,670 .

56 Mabbett (n 18) 101. 
tive legal authority in place to oversee implementation at the national level. Further, because of the Directive's inclusion of disability, with its unique conditions, the legal safeguards demand 'flexibility in the legislative approach traditionally used to combat discrimination as well as the introduction of new legal concepts into the national legal order of most Member States'. ${ }^{57}$

\section{Mainstreaming mainstreaming}

The above section details some of the main criticisms of the Framework Employment Directive. Yet the problems related to the disabled and equal opportunity are far more complicated and require a more comprehensive approach than what the Directive entailed. A good (and proven) starting place is the concept of mainstreaming.

Mainstreaming was introduced to the European Union in a 1993 Social Policy Green Paper, which defined the term broadly as the 'acceptance of people as full members of society, with opportunities for integrated education, training and employment, and to lead their lives independently'. ${ }^{58}$ Of course, as the description implies, mainstreaming is not limited to any particular group of people. Rather, it is a general framework for how to promote, organise, manage, and interpret the intentions of communitywide social programmes.

Mainstreaming is not simply a concept. Inclusive general policies, or 'mainstreaming', goes beyond the incorporation of non-discriminatory provisions in Community legislation, and provides for the inclusion of specific measures in general instruments to ensure that certain (minority) groups are able to benefit equally from Community policies. ${ }^{59}$

One of these equalising instruments could be the inclusion of a specification (taken from Article 95, now 100a), where the producers are forced to provide the minimum standards in order to ease the circulation of a certain product that takes into account the needs of disabled consumers. Such an approach should make less necessary separate instruments which only address certain groups individually.

Mainstreaming has been particularly important when applied to education and labour sectors. Specifically, it has helped to encourage administrative practices (at the national level) of integrating people from various backgrounds and abilities at 'ordinary' schools (rather than spe-

\footnotetext{
57 Richard Whittle, 'The Framework Directive for Equal Treatment in Employment and Occupation: An Analysis from a Disability Rights Perspective' (2003) 23 (3) European Law Review 303.

58 Mabbett (n 18) 101.

59 Waddington (n 22) 137.
} 
cial needs schools) or on the 'open labour market', respectively. As noted by Mabbett, mainstreaming seeks to avoid the various forms of institutionalisation. ${ }^{60}$

As it applies to the disabled in the workplace, mainstreaming gained a much needed level of recognition in the European Commission's 1997 Employment Report - an entire chapter was dedicated to the topic - and in the Luxembourg Employment Guidelines (1997), a comprehensive policy review that urged more activism in the EU labour market. Perhaps most important, and thanks in large part to Article 13 of the Treaty of Amsterdam, mainstreaming could be a potential key catalyst in recognising disability under the social model. Mainstreaming, as noted above, is not limited solely to affecting legislation. The concept of mainstreaming has been extended from social provision into the policy process. Fredman describes this as follows: 'Mainstreaming means that equality is not just an add-on or after-thought to policy, but is one of the factors taken into account in every policy and executive decision'. ${ }^{61}$ '[M]ainstreaming develops non-discrimination as a programmatic rather than a justifiable right, aiming for engagement in the sphere of policy making rather than seeking remedies for individuals'. ${ }^{62}$

Without mainstreaming, the Directive cannot fully reach its goal, since it only protects against discrimination in the labour field, which cannot be ensured without anti-discrimination protection of other labour related fields. Mainstreaming could play a significant role in this, since it is the most comprehensive way to achieve protection.

For example, success in employment is affected not only by employment and training initiatives, but by the availability of personal support, transportation, housing, flexible and supportive return to work in income programmes, the availability of jobs, and the attitude of employers. ${ }^{63}$ While measures and actions that are designed specifically for disabled people are important, it is also vital that all general measures aimed at increasing employment also take into consideration the needs of disabled people.

In fact, much of the concept's emphasis has been given to more tangible reforms, especially as it applies to the workplace. Those who promote its concept focus on where employment success can be more readily gained by such basic initiatives as increasing the availability of transpor-

\footnotetext{
60 Mabbett (n 18) 101.

61 Sandra Fredman, Human Rights Transformed. Positive Rights and Positive Duties (OUP 2008) 165 .

62 Waddington (n 22) 137.

63 Lisa Waddington, 'The European Community and Disability Discrimination: Time to Address the Deficit of Powers?' (1997) 12 (3) Disability \& Society 465, 470.
} 
tation, housing, personal support, flexible scheduling and return-to-work policies, as well as training and educational programmes for employers. ${ }^{64}$

Member States, while keen to embrace the symbolic connotations of mainstreaming, have been far less adaptive in implementing it into various national social policies, thus many of the concepts of mainstreaming remain limited to the Commission. Perhaps, if the NGOs - a key driver of anti-discrimination policy -were less susceptible to the same social policies that restrict national governments, or if the transnational NGOs promoting Communitywide anti-discrimination policies were given more importance, mainstreaming could flourish. However, Member States are more inclined to work with NGOs originating from their own country. This is not to say that transnational groups have not had some success in affecting the language of anti-discrimination policies; yet 'there is little agreement on how to take non-discrimination further in areas such as employment policy and social security'. ${ }^{65}$ Among the most poignant problems are that Member States, the Commission, and NGOs have been unable to create concrete targets for disabled people in terms of employment, have yet to produce relevant indicators that detail the inefficiencies of current policies, and too often act on insufficient information and analysis in terms of budgets and timeframes (that relate to disabled persons and employment).

In addition to the above-mentioned problems being rectified (or at least improved upon), mainstreaming, as it relates to the disabled, must involve two features. First, disability mainstreaming must include both employment targets as well as more general aims, including those related to improved consumer conditions. For example, the EU and Member States could help ensure harmonised consumer instruments that require a minimum standard - as it relates to the circulation of products in the common market - and takes into account the needs of disabled consumers. ${ }^{66}$ Second, the main stakeholders, ie employers and disabled persons groups, must improve their lines of communication so that both parties can adapt and profit from mainstreaming within the confines of the muddled, even contradictory, legislation and analysis that presently exists about disabled persons and their abilities to enter, participate, and advance in the workplace. The key reason is that employers are naturally drawn to one-size-fits all solutions as a means of streamlining both costs and objectives. Disabled persons, to date, have not been vocal enough in educating the private sector that their needs are highly individualised. In summary, mainstreaming requires a much more comprehensive and proactive approach in order to stimulate the ideals it champions.

\footnotetext{
64 Waddington (n 63) 470.

65 Mabbett (n 18) 101.

66 Waddington (n 22) 137.
} 


\section{The need for disability specific discrimination law}

In limiting the Framework Employment Directive simply to the employment field - excluding other areas such as goods, services, and transport provisions, as well as education - the EU has undermined the scope of protections for the disabled. As mentioned in the previous section, even if the sole purpose of the Directive is only labour related anti-discrimination protection, this cannot be achieved to its fullest without securing protection in other aspects of life. Of course, if the EU's true objective is to guard the disabled against discrimination, the legislation should go a step further and develop laws to protect the disabled in all foreseeable situations, for the sake of protection as a principle, rather than merely securing the efficient functioning of the labour market. This goal can be achieved only through specific disability legislation.

The disability movement in Europe since 1996 has demanded a 'disability specific' anti-discrimination law. ${ }^{67}$ As noted above, those with disabilities face a multitude of barriers that their peers do not, including environmental hindrances, community exclusion, and longstanding negative perceptions regarding their capabilities. By grouping disability with other forms of discrimination (those based on age, religion, and sexual orientation) as was done in the Directive, the needs of the disabled have become diluted or overlooked entirely. ${ }^{68}$

In 2003, the disability movement pushed for a new directive that would entail the entirety of their cause, ie, not simply employment factors, but those that encompass their everyday life, from eased access to consumer goods, transportation, and education. The EU responded with the EU Disability Action Plan 2003-2010 (DAP), which is simply that - a plan. It lacks the power to authorise Member States to enact real 'disability-specific' legislation. ${ }^{69}$

In this regard, the United States is far ahead of Europe. The ADA communicates and administers these disability specific concerns. Further, the American government has utilised its power to leverage the private sector to achieve an even greater amount of access for the disabled: private entities who conduct business with the government are required to meet a higher standard of access - both for employment of the disabled, and the easement of access to the products supplied by

\footnotetext{
${ }^{67}$ Rudolph Brynn, 'EU and Rights for Disabled People' (National Centre for Documentation on Disability, Norway, November 2000) <http://www.dok.no/eu-and-rights-for-disabledpeople-.565791-81731.html> accessed on 16 March 2009.

68 In fact, the controversy surrounding the inclusion of discrimination based on sexualorientation garnered the most attention as the directive went into effect.

69 Lisa Waddington 'A Disabled Market: Free Movement of Goods and Services in the EU and Disability Accessibility' (2009) 15 (5) European Law Journal 575, 590.
} 
these companies. On the whole, EU Member States have been hesitant to adopt similar measures, citing concerns that such 'social conditionality' distorts the open market. ${ }^{70}$

This is slowly changing. The EU Public Procurement Directive of 2004 openly stipulated that Member States could write legislation that encroached on 'social conditionality'; however, this directive far from required them to do so, which deems the success of the directive far less great. In an ironic twist on the general perceptions of the EU and the US, Europeans were seemingly more concerned about the fate of capitalism, rather than the equality of its citizens. Of course, some Member States have instituted policies that extend beyond the requirements of the $\mathrm{Di}$ rective, notably the Irish Disability Act of 2005.

For much of the period between 2000 and 2007, however, there was little evidence that the EU itself planned to extend the scope of disability law beyond employment, nor are there any plans to create a single equality body that would oversee all forms of discrimination (note: they do exist for race and gender discrimination). The reason for this reluctance is arguably the poor response of some Member States to the current Article 13 Directives and the anticipated difficulties of securing the adoption of future such Directives'. ${ }^{71}$

In 2008, following a year-long campaign by disabled groups that resulted in the submission of a petition signed by nearly two million EU citizens, the Commission began to right its past oversights. The Commission drafted a proposal to enhance the scope of disability rights beyond employment which makes specific mention of increasing disabled consumers' access to goods and services. The language of the proposal is as follows:

The measures necessary to enable persons with disabilities to have effective non-discriminatory access to... and supply of goods and services which are available to the public, including housing and transport, shall be provided by anticipation, including through appropriate modifications and adjustments. Such measures should not impose a disproportionate burden, nor require fundamental alteration of the...goods and services in question or require the provision of alternatives thereto. ${ }^{72}$

\footnotetext{
70 Gerard Quinn, European Disability Law: Outline, 'International Disability Law Seminar' Renmin University Law School, Beijing (11-12 January 2007).

71 Lisa Waddington, 'Taking Stock and Looking Forward: The Commission Green Paper on Equality and Non- Discrimination in an Enlarged European Union' (2004) 33 (4) ILJ 367, 374.

72 Council Directive (EC) 2000/78 (n 5) art 5.
} 
On the surface, this proposal seems to address the primary issue of expanding anti-discrimination rights for the disabled beyond the Directive (i.e., employment). Most notably, such a provision would force private establishments specialising in the goods and services trade to improve their accessibilities and arrangements for the disabled. No longer, for example, could a disabled patron be turned away from entering a nightclub on the basis that their disabilities draw undo attention from other customers. Yet, despite the proposal's intents, several problems exist regarding not only its functionality, but the functionality of any directive proposed under the current language of the Treaty of Amsterdam's Article 13.

The first major problem is that Article 13 does not have the ability to affect matters that deal with the internal market. As stated in the Treaty itself, Article 13 is 'without prejudice to the other provisions of [the] Treaty' and therefore other clauses in the treaty that involve the movement of goods and services take precedence; more specifically, Articles 94 and $95 .^{73}$

Second, the creation of community-wide disability standards is an enormous task. For standards to have a modicum of usefulness throughout the EU they need to be explicit. Directives that have been passed under the terms of Article 95 have proven to be insufficient in handling the technicalities needed to improve significantly disability access. Again, Member States are on their own to interpret and implement their own national standards. Then, the language of the 2008 proposal is rather limited in terms of 'reasonable accommodation'. There exists no remedy for cases involving a disproportionate burden, where the production of goods or services would have to be fundamentally amended in order to ease access for the disabled. Moreover, this appears to be an impossible feat given that some products would lose their usefulness and uniqueness if seriously altered, and many businesses would go out of business having to make such costly changes.

Third, any future legislation based on Article 13 requires the unanimous approval of the Council of Ministers. ${ }^{74}$ Even if twenty-six Member States were in agreement, it takes only one to nullify any proposed directive. In order to pass this proposal, the only incentive remains to find the least objectionable - and therefore least accommodating - measures that can be agreed upon by all Member States.

73 Waddington (n 69) 590.

74 Brynn (n 67). 


\section{Positive duties}

Much of the Directive and anti-discrimination laws in general focus on prevention and protection. Yet in order to ensure the full participation and equality of disabled persons in society, and especially in the workplace, the concept of positive duties must be implemented in future disability law. Traditionally the law has focused only on things that employers and colleagues should not do, ie treat people differently because of a physical or mental disability. The EDF, however, argues that in order to actually promote and attain the inclusion of a disabled person into society, directives must also reference positive duties (or positive actions). Such positive duties would include the inclusion of quota systems, strategies that improve communication between employers, governments, and the disabled, training and educational programmes, as well as financial incentives that reward those who provide better access to both the labour and goods and services markets. This trend is not limited to the EU; it has a growing relevance in international human rights law.

To further elaborate on the definition and reason for positive duties, they are categorised as 'duties to fulfil' rather than 'duties to protect'. In order to help define these often complex terminological differences, Fredman argues that there are four key criteria for positive duties: participation, accountability, effectiveness, and equality. '[E]ffectiveness requires that the state's action be appropriate; “...accountability" on the ground that the state has to "explain and justify the view taken of the steps to optimize the right". ${ }^{75}$ Participation requires the involvement of all those affected by such measures. The term equality needs no further elaboration.

Article 7 of the Directive allows Member States to adopt positive action policies; however, these have to date been limited mostly to quotas, which were already common prior to the Directive's completion. It is uncertain whether or not other preferences will be accepted, for example "preferences that "set-aside" certain low status jobs for persons with particular disabilities'. ${ }^{76}$ In spite of this, many EU Member States have, however, already begun to facilitate positive duties into their respective national laws. France, Luxembourg, Spain, Germany, the Czech Republic, and Italy have quota systems. Belgium provides financial incentives and job retention policies. Hungary, as noted above, includes some positive discrimination measures in their laws. Estonia provides up to $50 \%$ of the cost that employers incur as a result of adapting the workspace following the hire of a disabled person. The Estonian government also pays for

\footnotetext{
75 Fredman (n 61) 165.

76 Mark Bell, 'Equality and the European Union Constitution' (2004) 33 (3) ILJ 242, 252.
} 
technical support to employers who add a disabled person to their staff and provide the same support to disabled jobseekers. In Denmark, persons with physical disabilities are provided with assistants and granted tax exemption for transportation costs. The government also subsidises up to two-thirds of the salary for disabled persons as an incentive to get employers to hire more of them. Ireland, one of the EU's biggest champions of disability rights, has required that all public offices conduct staff training so that managers and employees have a better understanding of the Framework Employment Directive. Training is also provided to boards in charge of reviewing harassment cases in the workplace. To date, none of these provisions has been removed or challenged by the ECJ or national courts. ${ }^{77}$

One key hindrance in the EU prevents the further enactment of positive duties - and equality in general - as this pertains to anti-discrimination legislation. Many criticise that the concept of equality in the law needs to be widened. One of the new tools being promoted by the EU is the creation of bodies or boards whose sole function is to promote equal treatment. Member States are also obligated to create such bodies under the Directive. ${ }^{78}$

\subsection{Positive duties measured (inaccurately) by statistics}

A key reason why positive duties remain in place and continue to trend positively at the national level is that they have shown to be successful at integrating people into society as well as in the workplace. Yet, even in countries where positive duties exist, many statistics point to the downward trend of employment for the disabled. A primary reason for these discrepancies is that not all labour markets function equally. Further, there are widespread gaps in administrative protocols - both for employing the disabled and for measuring their employment status. For example, in Austria, the inactivity status for disabled persons is relatively low $(21 \%)$ when compared to the United Kingdom, France, and Ireland, each above $70 \%$. Yet the unemployment share for disabled persons is above $20 \%$, whereas in the other three countries it is in single digits. ${ }^{79}$ The only conclusion that can be drawn is that Austria uses a wholly different method of categorising its disabled persons. In spite of these discrepancies, the following section details some of the successes of po-

\footnotetext{
77 'Analysis by the European Disability Forum of the Transposition and Implementation of Council Directive 2000/78/EC Establishing a General Framework for Equal Treatment in Employment and Occupation' (European Disability Forum, 15 November 2007)

‘http:/ / cms.horus.be/files/99909/MediaArchive/Analysis\%20of\%20the\%20transposition\%20and\%20implementation\%20of\%20ETD\%20Revised.pdf> accessed 15 March 2009.

78 Bell (n 76) 252.

79 Shima, Zolyomi and Zaidi (n 1).
} 
sitive duties as well as their continued stagnation (or even decline) in EU Member States based on statistics. It should be noted that until there is a better convergence of Member State policies (discussed in the next section), these statistics will be limited in their ability to fully identify the effect of positive duties.

Across Europe, the general trend has been an increase in employment for disabled persons. The only two countries not to see an upward trend are Poland and the Czech Republic. At the same time, these two countries, along with Germany, France, Austria, Slovakia, and the United Kingdom), saw a decrease in unemployment among its disabled citizens. Unemployment rose in Belgium, Ireland, Latvia, Lithuania, and Malta.

One of the most common positive duties is the creation of Special and Separate Employment, also known as sheltered workshops. These often consist of various workshops that provide training and even full employment for persons with disabilities. Since 2000, employment participation for the disabled has increased in Germany, Austria, Finland, Italy, Luxembourg, and Portugal. Unemployment at sheltered workshops, however, has fallen in Poland and Sweden. In the case of Luxembourg, who along with France saw the biggest jump in participation in sheltered workshops, the government has incorporated a number of financial incentives. Disabled persons participating in the workshops receive a generous monthly stipend to help promote their eventual return (or entry) to the open labour market. In addition, those with disabilities are granted an extra week's paid leave from their employer, financed by the public. The United Kingdom has also seen a $12 \%$ increase in employment (and a decrease in unemployment) over the past decade. ${ }^{80}$ Though the UK abstains from instituting the quota system, the country has been at the forefront of other positive duties, including rehabilitation programmes and vocational training. These trends are encouraging, especially in light of the fact that only two of the twenty-seven Member States have seen a decline in employment for the disabled. Yet, given the varying methods of measuring employment/unemployment and active/inactive rates for the disabled, these figures remain open to the interpretation of the reader. The disparity among Member States' policies, however, is far more obvious.

\section{Member States' policies: a path to convergence or divergence?}

As mentioned above, the regulation of disability policies in the $\mathrm{EU}$ is handled almost entirely at the national level. Whereas some states have developed sufficient and specific legislation, others have not. Even where

80 Shima, Zolyomi and Zaidi (n 1). 
some have instituted disability legislation, they cannot all be classified as 'equal treatment' policies. This disparity calls into question whether or not there is even an EU-wide policy protecting disability rights. At the practical level, the divergence of policies complicates matters at the EU level, not only for the various courts, but also for persons relocating from one Member State to another. What the Directive has done is promulgate a convergence of vague anti-discrimination goals. Though this may be regarded by some as the early phases of the Europeanization of disability law, 'the mere existence of apparently similar lists of protected categories does not necessarily imply a parallel convergence in the wider policy context' ${ }^{\prime}{ }^{81}$ In order for disability rights to be achieved, the EU must work to create a convergence of policy as well as streamline the means to achieve its goals. As of today, the only actionable EU policy, or in this case protection, is that the Council 'may take appropriate action to combat discrimination based on sex, racial or ethnic origin, religion or belief, disability, age or sexual orientation'. ${ }^{82}$

The overall disparity of Member State policies derives, in part, from the fact that the Commission has only promoted general objectives. General objectives, as the term implies, lack authority and provide no means for how to obtain the desirable outcomes. Rather, general objectives are too often perceived to be mere statements of good will and a broad recognition of citizen concerns. A similar term, albeit one that carries much more weight and significance, is operational goals. Had the EU made operational goals part of the original Directive, not only could they have promoted Member States to pursue more universal policies, but also limited the total number of instruments required to meet these goals. ${ }^{83}$ Thus, the promulgation of operational goals is the first step toward minimising the large gulf that exists between Member States' disability policies.

An important question regarding the convergence of Member States' goals is whether or not various countries will (or are able to) move closer to one another without a revised Directive. Some continental-wide factors would suggest this may be the case. All of the countries in the European Union, to various degrees, are affected by the same societal trends: an aging population and a workforce that increases pressure on state and local level budgets, the competitive forces of the global market place, changing family dynamics that include parents and children of mixed national heritages, and the rise of immigration, especially from the south and east. Because Member States are experiencing the same trends, it would seem that their policies would eventually coincide to battle and

\footnotetext{
81 Bell (n 13) 43.

82 Mabbett (n 18) 101.

83 Bjorn Hvinden, 'The Uncertain Convergence of Disability Policies in Western Europe' (2003) 37 (6) Social Policy and Administration 609, 620.
} 
respond to similar challenges. Moreover, with the expanded network of international and supranational organisations, including the UN, ILO, EU and OECD, as well as the increased network of NGOs, there is a global trend toward addressing problems in the same manner. Not only are perceptions more universal, but also policies to correct and address issues are tending to derive from the same sources. The thinking among many is that convergence at this level will eventually find its way to the national level. As it applies to disability law, however, recent academic studies suggest that this is not in fact occurring.

Thus, the more viable option for creating a higher convergence of Member State policy is to fix the parts, rather than the whole. In addressing this issue, Hvinden notes that there are certain issues which are, as he terms, 'crowded' by already-established objectives, rules, measures and instruments. ${ }^{84}$ Because of all the external and internal efforts that have gone into providing for the above, issues that are 'crowded' are harder to adapt, reshape, or revise. As such, there is a higher cost to adjusting such policies, and, moreover, Member States are more reluctant to do so. Therefore, in order to create a higher convergence, the EU must target newer problem definitions and objectives, and not those, for example, that are specifically tied to the labour market. As stated above, these can involve the Danish tax-free exemption on transportation, the Irish mandate to train employees and board members on the rights of disabled, or the Estonian model of providing aid to unemployed disabled persons.

In addition to the disparate conditions of disability policy at the national level, there is a lack of convergence at both the academic and NGO level. In European academic circles, there has been an entire shift in the study of disability over the past three decades. Perhaps the greatest reason for this shift is the movement away from the medical model towards the social model. This has led to a minimum level of shared concepts and ideas; however, on the whole, the various national programmes diverge in a similar vein to those at the national level. Five northern European countries formed the Nordic Network on Disability Research, which holds an annual conference on disability topics and publishes a journal. Disabled academics in Germany have formed Netzwerk Disability Studies, which promotes the study of social models and trends in the field of disability. Universities in the United Kingdom have invested more in separating the study of disabilities from other similar fields. Though all of these various movements are deserving of praise, much can be improved in terms of promoting EU-wide academic forums, programmes, and publications. Further, the 2008 European Disability Strategy involved a number of high level convergences, bringing together the various appointed Member

84 Hvinden (n 83) 620. 
State experts on disability as well as a number of well-established NGOs. Academic representatives, however, remained largely absent from these proceedings. 'While such coordination is useful at the policy level, the academic community must urgently establish a parallel collaboration'. ${ }^{85}$

\section{Conclusion}

Unlike, for example, the common law countries, which have dealt with disability within a framework of civil rights and non-discrimination law, European countries have traditionally used their strong social model to combat this issue. While there is something to be gleamed from both approaches, the European one focuses on introducing a wider range of social policy changes, yet it lacks the focus on the disabled individual herself, which is the stronghold of the common law approach. Over the last twenty years, however, one can detect a notable shift away from the strictly social state approach in Europe towards a softer one, enriched with both anti-discrimination measures and civil rights instruments. Generally, the Treaty of Amsterdam is credited with requiring that the issue of improving opportunities for persons with disabilities be addressed from a human rights perspective rather than a social perspective. Article 13 is described as a 'quantum leap forward in the fight against discrimination at the EU level' and its adoption 'reflected the growing recognition of the need to develop a coherent and integrated approach towards the fight against discrimination'. ${ }^{86}$ The inclusion of disability in the Framework Equality Directive that originates from Article 13 presents an additional step forward in regrouping disability into an anti-discrimination law, advancing it farther away from welfare policy.

Even though the above described shifts present a positive and welcomed policy change, real progress remains slow. Few states have fully addressed disability as an aspect of anti-discrimination law; the UK, Sweden, and Ireland are notable exceptions. Many Member States have not made the best use of the implementation period, significant gaps remain between the language of the Directive and the language of the national regulations, and Member States still rely too heavily on individual litigation remedies.

In addition, there remains the much more comprehensive problem of the Directive only regulating discrimination within the labour market, which can hardly mitigate or prevent the overall discrimination of the disabled that would better secure their full inclusion in society. To achieve this goal, the EU would have to strengthen its efforts in the sphere of

85 Rasnic (n 12) 114.

86 Waddington (n 22) 137. 
mainstreaming, thus ensuring that the needs of the disabled are taken into consideration in all areas of legislation. Further, stronger emphasis would have to be given to the enforcement of positive duties, which would not only improve the situation of the disabled, but would also diminish the prejudice that exists towards them in the process. Finally, until there is better convergence in the way disability issues are dealt with among Member States, the European Union will not be able to achieve a unified and comprehensive approach in this domain. Until then, it is with hope that the ratification of the Treaty of Lisbon and its recognition of the European Charter of Human Rights will positively influence this issue. Time, however, is necessary in order to fully evaluate the Lisbon Treaty's impact here. 